\title{
Social Criticism through Humour in the Digital Age
}

Multimodal Extension in the Works of Aleix Saló

\section{Javier Muñoz-Basols and Marina Massaguer Comes}

\begin{abstract}
Numerous authors of comics and graphic novels have used the economic crisis in the Iberian Peninsula as a narrative frame for social criticism. Prominent amongst them is the Catalan cartoonist Aleix Saló, who burst onto the comics scene with his animated YouTube video Españistán, a book trailer for his graphic novel Españistán: Este país se va a la mierda [Españistán: This country is going to hell] (2011). This article shows how Saló offers a humorous and didactic portrait of the devastating effects of the economic crisis: he does this through multimodality (using specific shapes, colours, fonts and components of orality) and through creating 'multimodal extensions', intertextual relations between published books and book trailers. This analysis presents a case study of the multimodal techniques that authors use to shape and develop their work in the context of the powerful relationship between text and image in the digital age.
\end{abstract}

Keywords: Aleix Saló, book trailer, comics and graphic novels, economic crisis, humour, Iberian Peninsula, multimodal extension, multimodality

\section{The Origins of Aleix Saló's Humorous Universe}

In recent years, comics and graphic novels have experienced a boom in the Iberian Peninsula, attaining prominence in the literary landscape

\footnotetext{
We are greatly indebted to Aleix Saló for answering our questions and granting us permission to use his work. We are also grateful to Daniel Cassany (Universitat Pompeu Fabra) for his support, to Enrique del Rey Cabero for his valuable comments and to Pawel Adrjan for his helpful suggestions. Javier Muñoz-Basols acknowledges funding from the Spanish Ministry of Science and Innovation as part of the project entitled 'Digital Identities and Cultures in Language Education / Identidades y culturas digitales en la educación lingüística' (EDU2014-57677-C2-1-R).
}

European Comic Art Volume 11 Number 1, Spring 2018, 107-128 (C) European Comic Art doi:10.3167/eca.2018.110107

ISSN 1754-3797 (Print), ISSN 1754-3800 (Online)

This is an open access article under the CC BY-NC-ND 4.0 license. 
and becoming 'an intergenerational phenomenon transcending its traditional function of providing entertainment primarily for children and young adults, while expanding its reach to readers of all ages'. ${ }^{1}$ At the same time, comics and graphic novels have increasingly relied on current topics from the political and institutional spheres, such as the 2008 economic crisis, as narrative frames. ${ }^{2}$ Some of these works have even been described as handbooks of economics and economic critiques for the lay audience. ${ }^{3}$

Aleix Saló, born in 1983, is probably one of the most representative of the cartoonists committed to analysing the effects of sociopolitical and economic changes on individuals. Since entering the comics scene with his opera prima in Catalan, Fills dels 80: La generació bombolla [Children of the ' $80 \mathrm{~s}$ : The bubble generation], ${ }^{4}$ he has been giving a voice to the disappointment of those born between 1980 and 1989, whom Saló calls 'the bubble generation'. This generation inherited the transition to democracy in Spain and grew up in a country that was undergoing rapid economic and social transformation in the 1980s. That decade brought renovation, prosperity and the consolidation of a society that, as Saló himself acknowledges, foretold a promising future for this age group: 'Yo tenía compañeros y amigos, o incluso yo, que dábamos un poco por sentado que con hacer la carrera ibas a salir, se iban a pelear

1 Javier Muñoz-Basols and Micaela Muñoz-Calvo, 'Human Memory and the Act of Remembering in Contemporary Iberian Graphic Novels' in The Routledge Companion to Iberian Studies, ed. Javier Muñoz-Basols, Laura Lonsdale and Manuel Delgado (London: Routledge, 2017), 652-670 (652).

2 E.g. Miguel Brieva, Dinero [Money] (Barcelona: Random House Mondadori, 2008), Lo que me está pasando [What is happening to me] (Barcelona: Reservoir Books, 2015); Andrés Rábago 'El Roto', Viñetas para una crisis [Vignettes for a crisis] (Barcelona: Reservoir Books, 2011); Paco Roca, 'Crónica de una crisis anunciada' [Chronicle of a crisis foretold], El País Semanal (15 April 2012); Carlos Torres and Ona Peña, La máquina de hacer dinero: Quiénes y cómo fabrican las crisis económicas [The moneymaking machine: Who manufactures economic crises and how] (Barcelona: Ediciones B, 2011); Marcos Prior and Danide, Fagocitosis [Phagocytosis] (Barcelona: Ediciones Glénat, 2011); Juanjo Sáez, Crisis (de ansiedad) [Crisis (of anxiety)] (Barcelona: Penguin Random House, 2013); Aleix Saló, Españistán: Este país se va a la mierda [Españistán: This country is going to hell] (Barcelona: Editores de Tebeos, 2011); Aleix Saló, Simiocracia: Crónica de la gran resaca económica [Simiocracy: Chronicle of the great economic hangover] (Barcelona: Random House Mondadori, 2012); Aleix Saló, Europesadilla: Alguien se ha comido a la clase media (Barcelona: Random House Mondadori, 2013), trans. Lawrence Schimel as Euronightmare: Someone Devoured the Middle Class (Barcelona: Penguin Random House, 2014). All translations of non-English references and quotations are our own unless otherwise indicated.

3 Juan Royo, Un mundo en viñetas [A world in vignettes] (Zaragoza: 1001 Ediciones, 2012), esp. 54-55.

4 Aleix Saló, Fills dels 80: La generació bombolla (Barcelona: Ediciones Glénat, 2009). 
por ti y te pagaban un sueldazo' [I had colleagues and friends, and even myself, who took rather for granted that once you finished university, people would be desperate to hire you and you would make a lot of money]. ${ }^{5}$ Reality, however, turned out to be different. When the children of the 1980s reached adulthood, they became 'una generación hija del estado del bienestar que se dio de bruces con la precariedad laboral, la crisis económica y el paro' [a generation child of the welfare state that was thrown headlong into precarious jobs, the economic crisis and unemployment]. ${ }^{6}$

Witnessing first-hand the socioeconomic reality around him, Saló began to build the basis of his narrative universe in his first work, Fills dels 80 (Hijos de los 80 in the Spanish translation). ${ }^{7}$ Indeed, who better than a student of architecture to narrate the devastating effects of the Spanish property bubble? Saló portrayed the nostalgia of a generation whose shared dream of prosperity was truncated by the economic downturn. ${ }^{8}$ Nonetheless, as the author himself indicates, this first book did not earn him many readers. Learning from this experience, he therefore adopted a different strategy to popularise his second book, Españistan: Este país se va a la mierda (2011). To reach a wider audience, he created a video entitled 'Españistán, de la burbuja inmobiliaria a la crisis' [Españistán, from the property bubble to the crisis], an animated book trailer uploaded to YouTube on 25 May 2011, ${ }^{9}$ which the author would later describe as a 'winning horse'. ${ }^{10}$ In it, he narrates a well-documented, satirical chronicle of the causes and effects of Spain's property bubble. By combining multimodality with social criticism - and by having a trailer circulate in a digital media economy - Saló was able to rapidly generate interest amongst different types of audiences.

5 Juan Rodríguez Millán, 'Entrevista con Aleix Saló sobre Hijos de los 80: La generación burbuja [Spanish translation]' [Interview with Aleix Saló on Children of the '80s: The bubble generation], Comic Para Todos (15 September 2014), https:// comicparatodos.wordpress.com/2014/09/15/entrevista-con-aleix-salo-sobre-hijosde-los-80-la-generacion-burbuja.

6 Jesús Jiménez, 'La generación burbuja se dio de bruces con la crisis económica', Radio Televisión Española (9 September 2014), http://www.rtve.es/noticias/20140909/ aleix-salo-generacion-burbuja-se-dio-bruces-crisis-economica/1006362.shtml.

7 Aleix Saló, Hijos de los 80: La generación burbuja (Barcelona: Penguin Random House, 2014).

8 Tom C. Avendaño, 'Mi generación es tan útil como un Ferrari en un camino de cabras' [My generation is as useful as a Ferrari on a goat trail], El País (16 October 2014), http://elpais.com/elpais/2014/10/16/icon/1413478097_969475.html.

9 Aleix Saló, 'Españistán, de la burbuja inmobiliaria a la crisis', YouTube (25 May 2011), https://www.youtube.com/watch?v=N7P2ExRF3GQ.

10 Rodríguez Millán, 'Entrevista con Aleix Saló'. 
Hence, this innovative combination enabled Saló to whet viewers' curiosity with the aim of attracting them to the homonymous comic book. In this way, Saló earned greater prominence in the field of social criticism to become 'a kind of public intellectual whose opinion matters'. ${ }^{11}$ The result of his popularity was that he was able to reach the Spanish mass media as well as top-level politicians, including President José Luis Rodríguez Zapatero, who confessed to having seen the video. ${ }^{12}$

The popularity of Salós work is because of not only humour or drawing style, but also the informational and educational content so clearly evident in the meticulous documentation of the chronology of economic and political events, as well as the use of data and economic terminology. Keenly aware of the educational value that humour can confer, Saló made a point of inserting a range of anecdotes chronicling the progressive build-up of the events that created the economic crisis and the latter's origins in the property bubble (Figure 1).

The themes, the language and the simplicity of the lines in Salós comics display influences from two earlier generations of illustrators. ${ }^{13}$ The first includes a long list of cartoonists who were active during the final years of Franco's dictatorship through the transition to a well-consolidated democracy and who were working at several wellknown satirical magazines - for example Hermano Lobo (1972-1976), El Papus (1973-1976), El Jueves (1977) and Interviú (1976-2018) - as well as national newspapers - for example, Máximo (El País), Peridis (El País), Romeu (El País), Forges (Diario 16 \& El País), Chumy Chúmez $(A B C)$, Gallego \& Rey (Diario 16 and El País), Antonio Mingote $(A B C)$ and Summers $(A B C) .{ }^{14}$ They were followed by a second generation of cartoonists, which has been active since the 1990s and which comprises artists such as Paco Alcázar, Manel Fontdevila, Albert Monteys and Bernardo Vergara, who work with such magazines as Público, El Jueves and $E l$ Víbora and whose comics focus on satire and current affairs. Although these authors helped develop and sustain a strong tradition

11 Jaime Almansa Sánchez, 'To Be or Not to Be? Public Archaeology as a Tool of Public Opinion and the Dilemma of Intellectuality', Archaeological Dialogues 20, no. 1 (2013), 5-11 (9).

12 María Soledad Hernández Nieto, 'Aleix Saló: Crónicas de una crisis anunciada' [Aleix Saló: Chronicles of a crisis foretold], Revista Croma 1, no. 2 (2013), 46-50 (47).

13 Rodríguez Millán, 'Entrevista con Aleix Saló'.

14 Gerardo Vilches, 'Las elecciones generales en el humor gráfico de la prensa diaria (1982-1996)' [The general elections in the graphic humour of the daily press], in Historia de la época socialista: España, 1982-1996 [History of the socialist era: Spain], ed. Luis Carlos Hernando Noguera, Antonio Martínez, Abdón Mateos López and Álvaro Soto Carmona (Madrid: Asociación de Historiadores del Presente, 2011), 1-21 (4-5). 
SOM LA Teneració Bombolla

FilLS DE LA DEMOCRÀCIA, DE LA POSTMODERNITAT,

DE LA CRIST DE VALORS I DE L'ESTAT DEL BENESTRR.

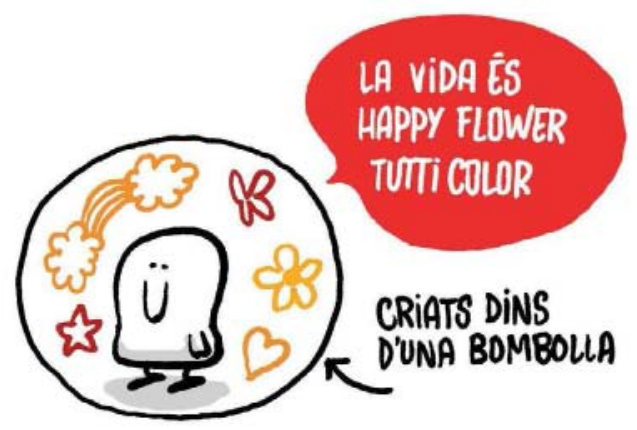

\section{i AiXí ESTÀVEM, CADASCUN DE NOSALTRES, ALLLUCINANT MANDONGUILLES, FiNS QUE VAM HAVER D'ESPAVILAR-NOS SOLS, i LLAVORS VA APARËXXER L'ALTRA BOMBOLLA...}

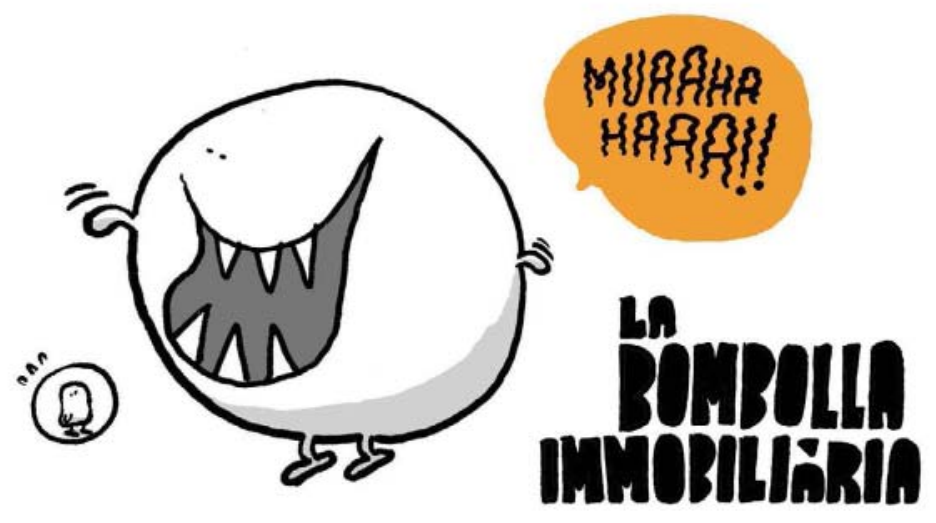

Figure 1: Saló, Fills dels 80 (14) [We are the bubble generation, children of democracy, of postmodernity, of the crisis of values and the welfare state. / Life is Happy Flower Tutti Color / Raised inside a bubble / And there we were, each one of us, happily dreaming, until we had to wake up on our own precisely when another bubble appeared ... / Muaaha haaa!! / The property bubble.] Reproduced with the kind permission of Aleix Saló. 
of graphic literature in Spain, their continued presence made it more difficult for a younger generation of artists to break through. In recent decades, while some have managed to achieve recognition - thanks in part to their enterprising spirit and to the support of small publishing houses - many have struggled to forge their way into the graphic genre. ${ }^{15}$ As Saló has described it, 'Jóvenes como yo, que querían publicar en El Jueves o La Vanguardia, los había a patadas y lo teníamos y lo seguimos teniendo muy complicado para dedicarnos a esto' [There were loads of young people like me, who wanted to publish in El Jueves or La Vanguardia, and it was - it is - difficult to work in this field]. ${ }^{16}$

This difficulty in gaining access to the traditional inner circles of illustrators was probably one of the driving forces that led Saló to explore other options to make his visual literature known. The promotion of his work using a book trailer was decisive. As we shall argue next, it is also closely linked to the multimodal components that Saló deliberately inserts into his graphic and audiovisual works - a multimodal extension that is at the reader's disposal.

\section{Multimodal Components in the Works of Aleix Saló}

Salós videos and comics are characterised by a high degree of intertextuality and by multimodality, that is the use of several semiotic modes in the design of a semiotic product or event, together with the particular way in which these modes are combined. ${ }^{17}$ This has to do with the way in which the cartoonist designs an array of different semiotic methods to produce humour. The system of signs becomes interpretable because of the design of a specific perception process, which is deliberately used by Saló to configure his narratives. ${ }^{18}$ Alice Leber-Cook and Roy Cook point out the following:

Comics, with their unique and powerful combination of picture and word, are multimodal text par excellence. As a result, comics are, on this new understanding of literacy and text, not only genuine texts - experience of

15 Gerardo Vilches, 'Entrevista con Aleix Saló', Entrecomics (22 September 2014), http:// www.entrecomics.com/?p=101458.

16 Jiménez, 'La generación burbuja'.

17 Gunther Kress and Theo van Leeuwen, Multimodal Discourse: The Modes of Media of Contemporary Communication (London: Arnold, 2001), 20.

18 Charles J. Forceville, 'Non-verbal and Multimodal Metaphor in a Cognitivist Framework: Agendas for Research', in Applications of Cognitive Linguistics: Multimodal Metaphor, ed. Charles J. Forceville and Eduardo Urios-Aparisi (Berlin: Mouton de Gruyter, 2009), 19-42 (22). 
which constitutes genuine reading - but are also particularly interesting and important examples of this wider understanding of text. ${ }^{19}$

Consequently, some examples of the use of multimodality in Saló's works are the lines and the shapes of the drawings, the different fonts and the use of colour (or its absence), but they also include a careful and evocative use of language, with phonological features originating from orality, which include changes in and the mixing of codes (i.e. words and expressions in English or the imitation of other languages), music and other sound effects, and cultural references to television, cinema or literature.

\section{Pictorial and Typographic Components}

From the point of view of the drawings, Saló configures his characters with simple, thick lines and shapes. His characters are generally schematic and, occasionally, have minimum facial traits (no nose or mouth and often no hair), and the scenes take place in open landscapes without a background. Saló claims to have been influenced by artists like Xavier Mariscal and Keith Haring. ${ }^{20}$

The fonts also play a part in Saló's multimodal universe, since he plays with the shape, size and colour of the letters that he draws, highlighting some keywords in order to evoke a diversity of connotations and meanings while simultaneously contributing to the humour of the scene. In spoken language, the semantic value of many of these words would be enhanced with the tone of voice and the intensity with which they are uttered. We can see this, for example, in the Españistán book trailer, in which Saló himself inserts the voice-over, or in Simiocracia ${ }^{21}$ through the utterances articulated by a group of speakers. For instance, there are the words 'TTú sí que vales!' [You are really worth it!], which were inspired by a homonymous TV show, that a multitude of voters shouted to the head of the Spanish government, Mariano Rajoy, after he won the general election in 2011. ${ }^{22}$ In his first book, Fills dels 80,

19 Alice Leber-Cook and Roy T. Cook, 'Stigmatization, Multimodality and Metaphor: Comics in the Adult English as a Second Language Classroom', in Graphic Novels and Comics in the Classroom: Essays on the Educational Power of Sequential Art, ed. Carrye Kay Syma and Robert G. Weiner (Jefferson, NC: McFarland, 2013), 23-34 (28).

20 Tesa Zalez, 'Españistán y Aleix Saló en Spanish Way.es', Spanish Way (22 July 2011), YouTube, https://www.youtube.com/watch?v=ZZiSm-CZLfM.

21 Saló, Simiocracia, 44-45.

22 Sonsoles Mayorga, 'Cientos de personas celebran en Génova la victoria del PP al grito de "Tú sí que vales"' [Hundreds of people celebrate the victory of the PP in Génova Street to the cry of 'You are really worth it'], Radio Televisión Española (21 November 2011), 
the cartoonist even fuses letters and drawings, for example, in the title 'Habitatge' [Housing], where the capital letter $A$ takes the form of a house. The use of different fonts to create meaning beyond what the words express is a constant in the evolution of the author's works. They are combined with the traditional practices of comics, such as the use of larger letters to indicate that a character is shouting.

In the same vein, the rare use of colour responds to the willingness to facilitate the reading experience and to make it more attractive and pleasant with an undiminished attention to the message. In Fills dels 80 and Españistán, Saló uses basic, compact colours - blue, green, yellow and orange - with no chromatic scale. On the other hand, in his more recent books, Simiocracia and Europesadilla, he does not use any colour. One can detect a clear evolution concerning the graphic aspects of his works: the loss of colour inside the book coincides with the increasing predominance of the text in conventional typed words, which take up more space as more data are provided and the social and political critique sharpens. Thus, while in Fills dels 80 and Españistán the drawings carried the burden of the narrative thread (Figure 2), in Simiocracia and Europesadilla the narrative is sustained mainly by the printed text, with black-and-white drawings visually reinforcing, illustrating and occasionally completing what is being told (Figure 3).

Saló begins drawing satirical vignettes in Fills dels 80 and follows with the graphic novel Españistán to arrive finally at the 'illustrated essays' of Simiocracia and Europesadilla. ${ }^{23}$ Such an evolution seems to indicate that the cartoonist wants to confer progressively more importance upon the message, while the way in which that message is transmitted serves to emphasise its content. That is, Saló evolves from creating short stories with a satirical tone to writing informative books with a social critical discourse, with vignettes that illustrate what is being explained and that help to interpret it. Significantly, Saló asserts that he considers himself more of a cartoonist than just an illustrator, and he acknowledges the influence of cartoonists such as Jaume Perich and Andrés Rábago ‘El Roto' on his work. According to Saló, the cartoonist 'utiliza el dibujo más como una herramienta que como un fin, una herramienta para explicar cosas, en este caso la actualidad' [uses drawings as a tool more than an end, a tool to tell things, in this case, current affairs]. ${ }^{24}$ Thus, a possible explanation of the author's aesthetic

http://www.rtve.es/noticias/20111121/cientos-personas-celebran-genova-vistoriadel-pp-grito-mariano-tu-si-vales/476903.shtml.

23 Vilches, 'Entrevista con Aleix Saló'.

24 Zalez, 'Españistán y Aleix Saló'. 
LES CONDiCiONS DEL [M] ERSGG] NO BEMPRE HAN EOTTT LES MATEIXES.

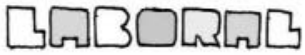

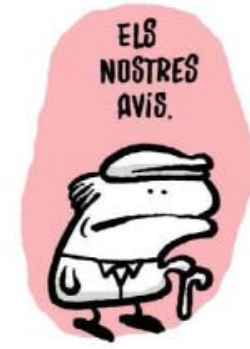

NO VAN PODERESTUDIAR i HAN TREBALAT TOTA LA VIDADE $\mathbf{X}$.

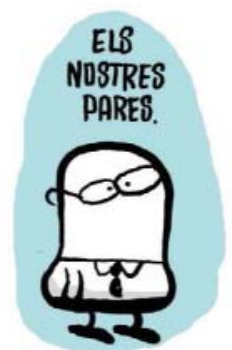

VAN ESTUDIAR $\boldsymbol{X}$ i HAN TREBALLAT TOTA LA VIDA DE $\mathbf{X}$.

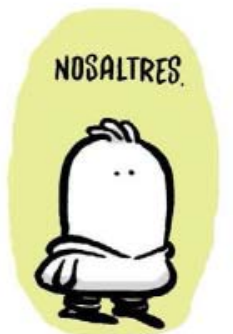

HEM ESTUDiAT $\boldsymbol{X}$ I l'ÚLTIM ANY HEM TREBALLAT DE $\boldsymbol{\nu}$, $D E \boldsymbol{Z}, D E \mathbf{W}$, DE $B$ H, DE E, ...

Hi HA ALGÚ DE LA GENERACIÓ BOMBOLLA

QUE ESTIGUI TREBALLANT D'AUL̃ QUE VA ESTUDIAR

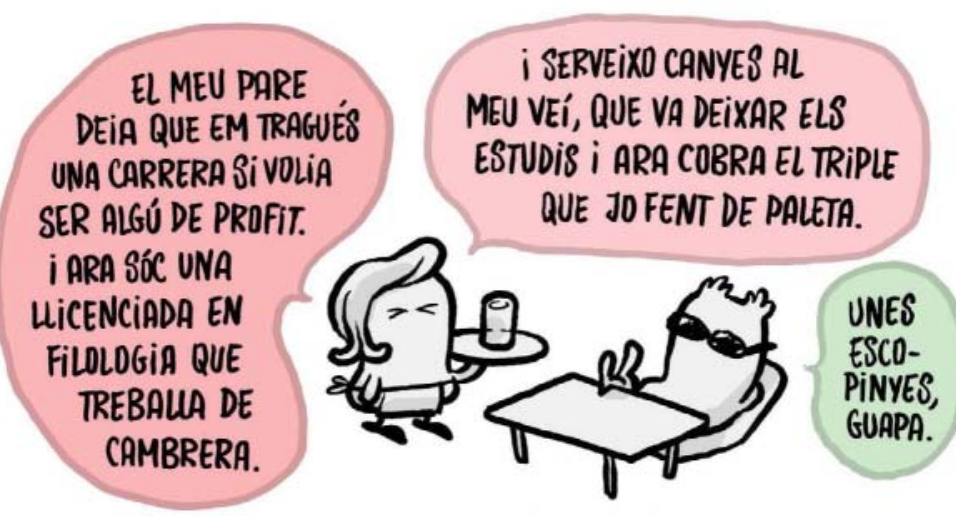

Figure 2: Saló, Fills dels 80 (68) [Labour market conditions have not always been the same. Our grandparents: they could not study and they worked their whole life as ' $X$ ' / Our parents: they studied ' $X$ ' and they worked their whole life as ' $\mathrm{X}$ ' / Us: we studied ' $\mathrm{X}$ ' and during the last year we have worked as ' $\mathrm{Y}$ ', as ' $\mathrm{Z}$ ', as ' $W$ ', as ' $\mathrm{H}$ ', as ' $\mathrm{F}$ ' . . . I Is anyone from the bubble generation working in the field they studied? / My father told me to get a degree if I wanted to be someone. Now I am a graduate in languages, and I work as a waitress. / And I serve beer to my neighbour, who left school and now, as a construction worker, makes three times what I do. / Some clams, darling.] Reproduced with the kind permission of Aleix Saló. 
Tu "yo" del año 2009.

Tu "yo" del 2012.

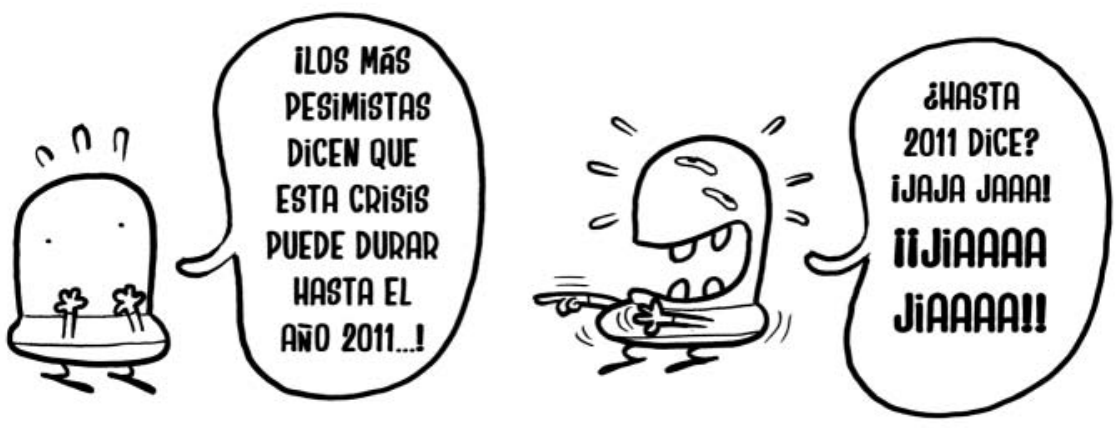

Aún así, el presidente del Gobierno continuaba apelando a la antigua "verdad colectiva" del optimismo, pensando que sería suficiente para mantenernos a flote.

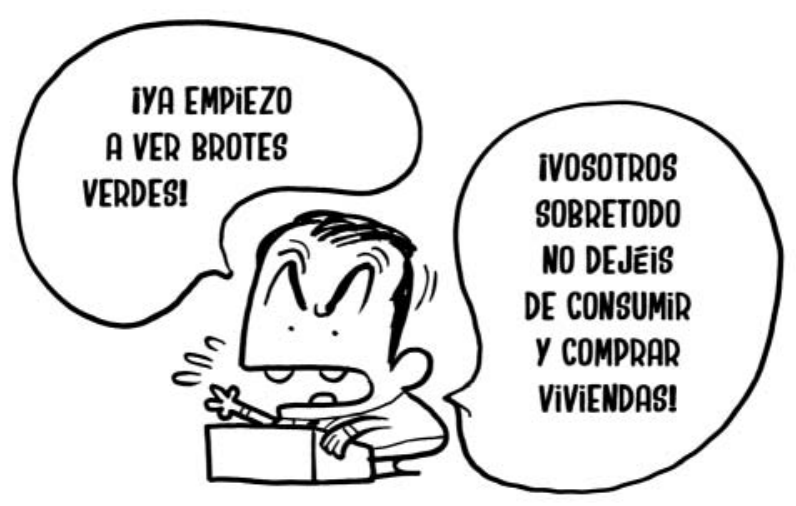

Figure 3: Saló, Simiocracia (114) [You in 2009. / The biggest pessimists say that this crisis may last until 2011 . . .! / You in 2012. / Until 2011, he says? Ha, ha, ha! / Even so, the president kept invoking the old 'collective truth' of optimism, thinking that it would be enough to keep us afloat. / I am starting to see green shoots! / Above all, don't stop consuming and buying houses!] Reproduced with the kind permission of Aleix Saló. 
choices is that he understands art as a means of reaching a wide audience with his critical message by using a plain and simple style that is capable of transmitting a complex message (e.g. about economics or finance) and thus making this message accessible to everyone.

\section{Aural and Cultural References}

In terms of creating meaning, Saló's work contains multimodal features related to orality. Saló uses these features as a strategy to get close to the readers and make them identify with how the message is being communicated. Examples of this orality are numerous: onomatopoeias such as 'txunda, txunda' to imitate techno music (Fills dels 80, 48) and others inspired by classic superhero comics such as ‘¡Pum! ¡Paf! ¡Faapáh!' in Españistán (71), rude expressions such as 'cagontó' [I shit on everything] and 'quién tiene la puta culpa' [whose fricking fault is it?] in Simiocracia $(13,67)$, or words from young people's jargon such as ‘¡Chao pescao!' [Bye fish] and ‘'Soy lo puto más!' [I am the fricking shit] in Europesadilla $(105,134)$. Often these expressions have been popularised by TV shows, prominent examples being 'neng' [mate] and 'tontolaba' [doofus] in Españistán $(16,70)$ and 'iQué fuerte! ¡Qué fuerte!' [Unbelievable! Unbelievable!] in Simocracia (49). Saló also uses invented proper names with phonetic games that create a humorous effect (e.g. 'Ariqui Town' in Españistán (13) and 'Bank of Ziripollen' in Simiocracia (5)). Another common occurrence is the mixing of linguistic codes in colloquial expressions such as 'We are la polla in vinegar' in Simiocracia (1), which is a variation of the exclamatory expression 'Somos la polla en vinagre' [We are the shit], which can be used in a positive or negative way. Still regarding phonetic games, we can find stereotyped reproductions of Chinese speakers' speech when they speak Spanish, which mainly consist of pronouncing the ' $r$ ' sound as an ' 1 ' and using all verbs in the infinitive - 'No pleocupal. Gandolfo sel buen homble. Él muy jodido pol pensión de mielda (. . .). Nosotlos adoptal.lo pol pena' [Don't wolly. Gandolfo good man. He messed up because of his clappy pension. We adopted him out of pity] in Españistán (22) and, in parallel, those from Spanish speakers when they speak English, which are mainly based on a transcribed imitation of the pronunciation of consonants and vowels. One example is 'Hello' - 'Jeeeeloooou (. . .) Aim de president of Espaaain' [I am the president of Spain] - in Simiocracia (94). There are also imitations of French articulation, such as 'Je suí totalement cubiegt du miegd' [Je suis totalement recouvert de 
merde (I am totally covered in shit)] in Europesadilla (160). In this way, Saló displays a set of resources that create humour on the basis of phonetic and semantic associations, humour that is directed towards both the comic reader and the video watcher.

With regard to the intertextuality with cultural icons, allusions to television, cinema, pop music, literature, art and philosophy are frequent: amongst others, we can find references to the Telecinco TV channel dating show Hombres, mujeres y viceversa [Men, women and vice versa] $(17,26)$, the film Gone with the Wind (27) and the pop star Alejandro Sanz $(64,65,66,69,70,71,72)$ in Españistán; references to George Orwell's 1984 and Delacroix's painting Liberty Leading the People in Simiocracia (36, 37, 100, 40); and references to Plato's Allegory of the Cave both in Españistán (59) and in Simiocracia (14, 15).

Other strategies adopted by Saló in his last two works, Simiocracia and Europesadilla, to get closer to the reader include the use of the first person singular and self-portraying and introducing himself as a character to explain his personal experiences as a way of illustrating his message (Simiocracia, 22, 53, 80, 112).

It is with this set of visual and discursive strategies that Saló constructs his pictorial and narrative universe, strategies that are based on a multimodal approach whose objective is to convey a socially critical message. As the author himself claims, he analyses current affairs in a way that makes them appear 'more human' than the chronicles in other recognised sources. ${ }^{25}$

\section{Semiotic Modes as a Narrative Frame for Social Criticism}

The titles of Saló's videos and comics are evidence of the author's careful use of language. 'Ratzinger Z', ${ }^{26}$ a two-minute video that he created for the occasion of Pope Benedict XVI's visit to Barcelona in November 2010, is a good example. By means of paronomasia (i.e. the use of words that sound similar to create a specific effect), this cartoonist establishes a phonological parallelism between the Pope's last name Ratzinger - and the manga cartoon series from the 1970s, Mazinger $Z$. Saló thus succeeds in building a humorous narrative that transforms Pope Benedict XVI into a superhero combatting everything that threatens Catholic dogmas, such as abortion and homosexuality. Saló also

25 Iker Zarallo Peretó, 'Entrevista a Aleix Saló', La Finestra Digital (25 April 2013), YouTube, https://www.youtube.com/watch?v=7BF-AD-f1CI.

26 Aleix Saló, 'Ratzinger Z (el Papa a Barcelona)', YouTube (4 November 2010), https:// www.youtube.com/watch?v=Mmt1rnJ_a40. 
reinforces the ideas that the images transmit with background music from the 1960s American series Batman.

Something similar happens with the word Españistán, where semiotic traces combine to create new meanings. The morphological crossing between the noun 'España' [Spain] and the suffix '-stán' is easily identifiable with former Soviet republics in Central Asia (Kazakhstan, Kyrgyzstan, Tajikistan, Turkmenistan, Uzbekistan) or with countries like Pakistan or Afghanistan, which frequently appear in the media as political conflict areas. Indeed, the humorous new word Españistán in the title might make audiences curious about what this 'new country' would be like. In the introduction to Simiocracia, Saló explains that this title is an adaptation of the word Hispanistán, which appeared in Burbuja.info, an internet forum that started to warn people about the effects of the property bubble well before the mass media began to speak about it openly. Yet another reference that explains how Saló came up with the name Españistán may have been the 10 December 2001 cover of The New Yorker with the comical name 'New Yorkistan'. ${ }^{27}$

This type of humour, in which the author plays with the evocative meanings of selected words, together with the different semantic associations their sounds suggest, constitutes one of the more remarkable multimodal components of Salós work. Moreover, in the book trailer Españistán, the multimodal aspect is reinforced by the use of music and sound effects. For example, at the end of the video, a skinny cow appears to the sound of Middle Eastern background music, thereby reaffirming the humour evoked by the drawings through the effect of 'anchoring' the viewer-listener in this imaginary Españistán, where poverty and political chaos are the norm (Figure 4).

The nomenclature selected for the titles of Saló's works also demonstrates his use of word games to evoke a kind of cultural hybridisation between two worlds. Giving his figures an exotic charge, the author both moves us to this new place and invites us to explore it, much like the Canadian cartoonist Guy Delisle does. ${ }^{28}$ Significantly, he uses the same strategy as in his other books: condensing the main idea in the title by using a single compound word to summarise each book's topos and then following it up with an explanatory subtitle.

27 See Javier Muñoz-Basols, Pawel Adrjan and Marianne David, 'Phonological Humour as Perception and Representation of Foreignness', in Irony and Humour: From Pragmatics to Discourse, ed. Leonor Ruiz Gurillo and Belén Alvarado Ortega (Amsterdam: John Benjamins, 2013), 159-188 (161).

28 Santiago García, La novela gráfica [The graphic novel] (Bilbao: Astiberri, 2010), 254. 


\section{8}

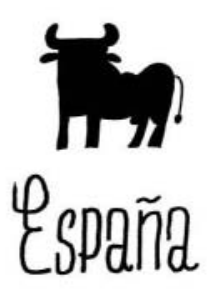

\section{8}

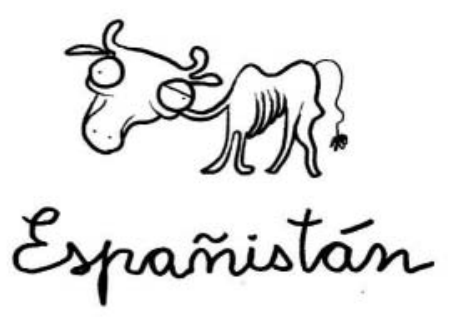

Figure 4: Frame fragments from the book trailer Españistán (6:25-6:28). Reproduced with the kind permission of Aleix Saló.

In his third book, Simiocracia: Crónica de la gran resaca económica, in which he deals with the same sociopolitical theme, the author offers an 'illustrated handbook' of the origins of the crisis, which includes historical analogies and autobiographical elements, ${ }^{29}$ so much so that Saló - who is well aware of the educational value of his comics - offers at the end of Simiocracia a list of recommended media sources concerning the political and economic issues involved for readers interested in familiarising themselves with the relevant economic concepts. ${ }^{30}$ These recommendations of specialised sources encourage readers to go beyond their own reading of the comic and thus develop a critical spirit nourished by the data offered them therein.

It is in his fourth book that, as an author committed to the reality that surrounds him, Saló jumps into the European context by internationalising his socially critical discourse. In 2013, in Europesadilla: Alguien se ha comido a la clase media [Euronightmare: Someone 
devoured the middle class], he puts the international crisis into the institutional sphere, questioning the actions taken by the European Union and portraying the instability of European values. Shifting from his first book in Catalan, in which he portrays the difficulties faced by his generation, to his second book, in which he denounces the Spanish sociopolitical reality, Saló now goes a step further in the evolution of his work by internationalising his literature: 'Necesito informarme mucho, leer, formarme e informarme (. . .) me gustaría viajar a Bruselas. El ambiente del Parlamento Europeo me parece que es un gran objeto a descubrir por parte del gran público, me da la sensación de que faltan voces que expliquen Europa desde la cultura popular' [I need to do a lot of research, read, educate myself and get informed (. . .) I would like to travel to Brussels. It seems to me that the atmosphere of the European Parliament is a big topic for the general public to discover. My feeling is that there is a lack of voices explaining Europe from the point of view of popular culture]. ${ }^{31}$

Starting with the outbreak of the financial crisis in 2008, the economy became part of pop culture. Economic terminology (e.g. toxic assets, vulture funds and risk premium) has progressively been included in the lexical repertoire of the non-specialised audience ${ }^{32}$ - again, thanks to the role of mass media. In this context, Saló declares: 'Ante la extrema complejidad de la actual coyuntura económica, cuyas enrevesadas reglas suelen ser la coartada perfecta para ocultar todo tipo de abusos y corruptelas, creo que cualquier tentativa de divulgación es poca, aunque venga de la mano de la sátira' [Given the extreme complexity of the current economic situation, whose difficult rules frequently create the perfect excuse to hide all kinds of abuses and corruption, I believe that any attempt at dissemination is worthwhile, even if it comes in the form of satire]..$^{33}$

Phenomena like the book Le Capital au XXIe siècle by the French economist Thomas Piketty, ${ }^{34}$ which, despite being relatively technical, attained a remarkable popularity once translated into English as Capital in the Twenty-First Century, confirm the increased interest in the economy by a significant group of the population. At the same time, the key

31 Rodríguez Millán, 'Entrevista con Aleix Saló'.

32 Javier Muñoz-Basols and Danica Salazar, 'Cross-Linguistic Lexical Influence between English and Spanish', Spanish in Context 13, no. 1 (2016), 80-102 (89).

33 Saló, Simiocracia, 'Introducción'.

34 Thomas Piketty, Le Capital au XXIe siècle (Paris: Seuil, 2013), trans. Arthur Goldhammer as Capital in the Twenty-First Century (Cambridge, MA: Harvard University Press). 
role that a work's translation can play in its dissemination at the international level can also be said to apply to the graphic genres. ${ }^{35}$

Choosing topics that concern the general public and including common sociocultural references are the principal tools that Saló uses to bring his work to an international audience by way of translation. His latest output of graphic literature has been translated into different languages, thereby internationalising his message. As part of his works' multimodal extension, Saló uses different strategies for his books and for his videos. Notably, in the book trailers 'Españistán', 'Simiocracia'36 and 'Europesadilla', ${ }^{37}$ a voice-over narrates the events. On the other hand, in the video 'Ratzinger Z' and the book trailer 'Euronightmare', ${ }^{38}$ the narrative sequence and the changes of scene are set by images and sound effects along with intertitles and overprint information - in Catalan in the case of 'Ratzinger Z' and in English in that of 'Euronightmare'. All of these multimodal elements are sufficient for the narrative and humorous sequence. In 'Euronightmare', Saló divides the world into different kinds of collective regional perceptions: what Americans think about Europe and vice versa, as well as what Western Europeans think about Eastern Europe and vice versa. The same holds for Northern and Southern Europe and for the United Kingdom and continental Europe.

In so doing, Saló creates humour by evoking stereotypes about different cultures and using a representational strategy that can also be found in other textual genres. ${ }^{39}$ For example, the vision of the United States by Europeans is that of an obese man sitting in a motorised wheelchair, who crosses the screen as he shoots a submachine gun. In contrast, the vision of Europe by US citizens is condensed into a scene set on a terrace in Paris, with the silhouettes of other European capitals in the background, where a waiter brings the customers a bill in which the tax is ten times the gross price. The absence of a voice-over allows these videos to cross linguistic and political borders. This absence of

35 Javier Muñoz-Basols and Enrique del Rey Cabero, 'Translation of Hispanic Comics and Graphic Novels', in The Routledge Handbook of Spanish Translation Studies, ed. Roberto Valdeón and Africa Vidal (London: Routledge, forthcoming, 2019).

36 Aleix Saló, 'Simiocracia', YouTube (9 April 2012), https://www.youtube.com/ watch?v=TfRSfF296js.

37 Aleix Saló, 'Europesadilla', YouTube (3 April 2013), https://www.youtube.com/ watch? $\mathrm{v}=\mathrm{BF} 0 \mathrm{bGaQCn} 04$.

38 Aleix Saló, 'What the UNITED STATES Thinks of EUROPE [Euronightmare]', YouTube (22 October 2014), https://www.youtube.com/watch?v=WDqayC1sR7g\&t=26s.

39 Carolene Ayaka and Ian Hague, 'Introduction', in Representing Multiculturalism in Comics and Graphic Novels, ed. Carolene Ayaka and Ian Hague (New York: Routledge, 2015), 1-16 (2). 
a voice is compensated for by common cultural references: from the monuments of the urban landscape of different cities that have become European symbols, such as the silhouettes of the Eiffel Tower, Saint Peter's Basilica, Big Ben, and the Leaning Tower of Pisa in the trailer of the book Euronightmare, to well-known international characters like the Pope in 'Ratzinger Z' or Conchita Wurst in Euronightmare, the latter being the bearded female singer who won the Eurovision Song Contest in 2014. It is in this way that the narrative thread is sustained by images, music and sounds, which, together with the receiver's encyclopaedic knowledge, produce meaning. In his latest book trailer, Saló even went a step further by parodying the United Kingdom as a state going repeatedly through a door marked 'Exit', thereby anticipating the outcome of the Brexit referendum that would take place two years later in 2016 (Figure 5).

Saló's discourse and humour have become increasingly global, given how his humour is always created on the basis of concrete cultural references. In the current European and international context, these shared references are becoming common, something which in turn allows readers to readily interpret their unequivocal message. The use
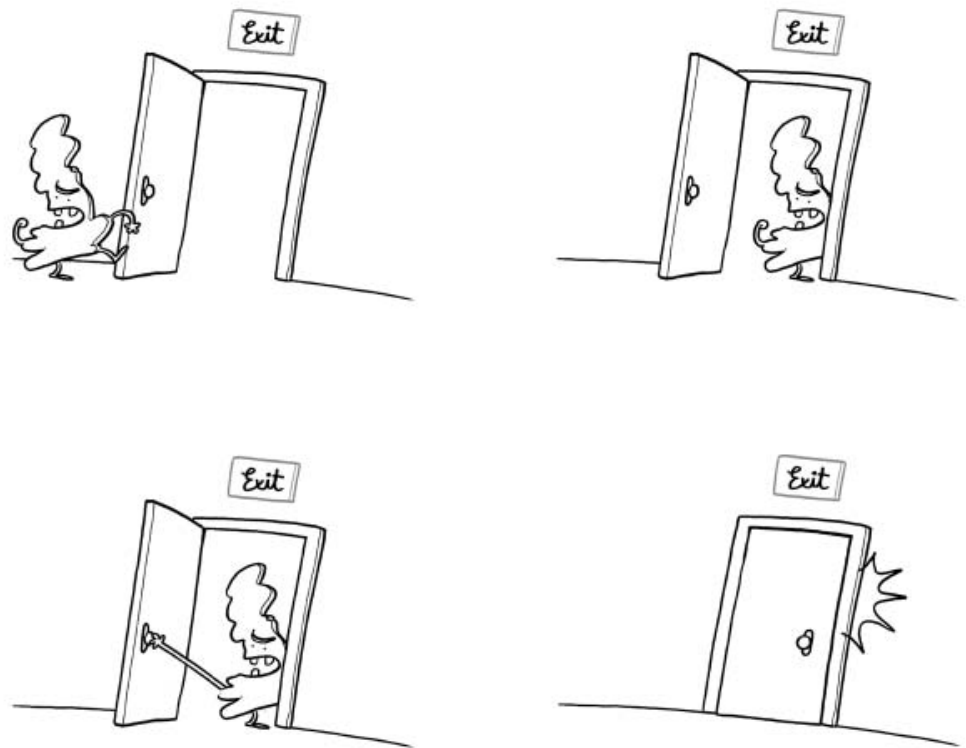

Figure 5: The United Kingdom 'exiting' the European Union. Frame fragments from the book trailer 'Euronightmare' (2014) (1:26-1:36). Reproduced with the kind permission of Aleix Saló. 
of fictional templates allows Saló to find a wider audience outside Spain and meaningfully shape his narrative of social criticism in a wider European context. As we will see next, the use of The Lord of the Rings, a well-known fictional template, as a narrative framework for the story in Españistán fulfils the objective of presenting the reader with a familiar plot with which s/he can easily identify.

\section{From the Book Trailer to the Comic Book and Back: The Multimodal Extension}

Saló argues that the YouTube video was a decisive factor in his reaching a substantial number of readers, thus making it possible to further his career as a cartoonist. According to Kati Voigt:

In a globalized world which is more and more ruled by mass media and technology, it is increasingly difficult for writers and publishers to promote their books. The solution is almost ironic: popular media, which is assumed to decrease readership, is turned into a tool to increase the number of readers. ${ }^{40}$

Even though ease of access to information and the low cost and the speed of distributing electronic media have progressively helped the latter replace books in their traditional format, ${ }^{41}$ the book trailer is a clear example of how technology can be used to draw readers to the printed book. ${ }^{42}$ In fact, David Barnett puts it this way:

[Across the United States and beyond] both print and digital sales are growing. Print comics more than match the rise in digital sales (.. .). While almost all forms of print media are down, comics are up, graphic novels are up, and digital comics sales are up. We are seeing that one feeds the other, people get hooked on digital, and end up going to stores to buy physical copies, or the reverse. ${ }^{43}$

After his opera prima, Saló began using the book trailer as a multimodal extension of the multimodal universe of his books. With the book trailer, the author endeavours to give life to his characters in a kind of 'visual entrée' to what the reader will discover in the paper

40 Kati Voigt, 'Becoming Trivial: The Book Trailer', Culture Unbound: Journal of Current Cultural Research 5, no. 1 (2013), 671-689 (671).

41 Albert N. Greco, Jim Milliot and Robert M. Wharton, The Book Publishing Industry (New York: Routledge, 2013), 57-58.

42 Jeremy Hyler and Troy Hicks, Create, Compose, Connect! Reading, Writing, and Learning with Digital Tools (New York: Routledge, 2014), 74-76.

43 David Barnett, 'Comics Capture Digital Readers - and Grab More Print Fans', Guardian (3 July 2015), https://www.theguardian.com/books/2015/jul/03/comics-capturedigital-readers-and-grab-more-print-fans. 
book. Thus, in his most popular comic, Españistán: Este país se va a la mierda, he narrates the history of the unemployed youngster Fredo, whose name is inspired by Frodo, the main character of The Lord of the Rings. Together with Samu, a graduate in design (Salós alter ego), and Gandolfo, a pensioner, Fredo embarks on a journey to get rid of a mortgage that he cannot afford. Despite the common narrative of denouncing the causes of the Spanish economic crisis, in the elaboration of the video and the comic, Saló was aware that he was looking for two different types of public: the comic contained a more adolescent humour, while the video was aimed at a wider audience, everyone from teenagers to the elderly. ${ }^{44}$

By means of the parallelism established in creating the video and the comic, Saló accomplished a 'multimodal extension' of this work, that is to say, the use of audiovisual media that broadens and/or complements an author's work (in this case, between the published books and the book trailers) by creating relations of intertextuality. In a digital media economy, consumers are precisely being empowered to interact with the content. ${ }^{45}$ Through conscious design, the author attempts not only to disseminate a specific piece of work but also to engage with the audience by shaping and developing his work in the context of the powerful relationship between text and image in the digital world. Hence, as Saló explains, the dependence between the book trailer and its printed works becomes relevant in his narrative universe, given that his intention was precisely that the video 'completara un poco la visión y la historia que cuenta el cómic' [serve to complete the vision and the story narrated in the comic]. ${ }^{46}$ He states as much in Simiocracia:

És interessant el joc que es dóna d'anada i tornada, del llibre al vídeo, perquè el llibre cada cop s'assembla més al vídeo, al contrari que a Españistán. És a dir, al llibre ara hi ha molt més text que podria ser una mica com la veu en off que sona en els vídeos, i és interessant aquest joc que es genera, i sobretot en el moment en què estem, en què sembla que els llibres estan patint una crisi de suport; jo crec que se'ls pot encara donar molta vida i crec fermament que si va de la mà d'Internet d'una forma intel-ligent, es poden sumar molt els dos llenguatges, el llenguatge audiovisual i el llenguatge de llibre (. . .) encara no he trobat autors de còmic que utilitzin el doble format de treball de llibre/vídeo. Llavors, en això encara sóc inexpert i encara estic

44 Televisión Española: Canal 24h, 'Españistán y Aleix Saló en TVE24h', YouTube (13 June 2011), https://www.youtube.com/watch?v=uS8Sg0XJy5o.

45 Giuditta de Prato, 'The Video Games Industry', in Digital Media Worlds: The New Economy of Media, ed. Jean Paul Simon, Esteve Sanz and Giuditta de Prato (New York: Palgrave Macmillan, 2014), 163-179.

46 Televisión Española: Canal 24h, 'Españistán y Aleix Saló en TVE24h'. 
buscant a veure com ha de funcionar la fórmula perquè una cosa completi l'altra però a la vegada el vídeo tingui entitat per la seva banda i el llibre tingui entitat per la seva banda. ${ }^{47}$

[The back-and-forth between the book and the video is interesting because the book increasingly resembles the video, while the opposite happened in Españistán. That is to say, the book now contains much more text, a bit like the voice-over in the video. This is an interesting kind of interaction, especially in the moment we are living in, when it seems that books are going through a crisis. I think that it is still possible to give them a lot of life, and I firmly believe that if it goes hand-in-hand with the internet in an intelligent way, both languages can complement each other: the audiovisual language and the language of the book (...). I have not yet found comics authors that work in this twin book/video format. I am not yet an expert at this, and I am still looking for how this formula should work. While one format completes the other, both the video and the book have their own reasons for being.]

Saló carries out a similar multimodal extension with the book trailers for Simiocracia and Europesadilla. These videos not only contribute to publicise the books, but they also complement them by providing new information and completing the main message. The author tailors the type of discourse to each format, but they are deeply interconnected, so together they contribute to broaden the scope of the work. Through the multimodal extension, Aleix Saló not only finds a useful platform to make his works popular, but his intention responds also to the idea of providing the reader with a multimodal vision of his literature, which is more complete and contributes to create new meanings while reinforcing the message and its relevance in order to reach new audiences. The fact that his latest book was published both as a paperback and as an e-book not only in Spanish, as Europesadilla: Alguien se ha comido a la clase media, and Catalan, as Euromalson: Algú s'ha cruspit la classe mitjana, but also in other languages, such as Portuguese, Euro Pesadelo: Quem comeu a classe média?:;8 English, Euronightmare: Someone Devoured the Middle Class; and Turkish, Eurokâbusu: Biri orta sinifi yedi, ${ }^{49}$ speaks volumes about the capacity of Saló's narratives to transcend national borders.

Digital comics and the digital media constitute, after all, 'a gateway to print'. ${ }^{50}$ Saló is a pioneer in the combination of videos and printed

47 Zarallo Peretó, 'Entrevista a Aleix Saló'.

48 Aleix Saló, Euro Pesadelo: Quem comeu a classe média?, trans. J. Pereira (Lisbon: Bertrand Editora, 2013).

49 Aleix Saló, Eurokâbusu: Biri orta sinifi yedi, trans. Arda Koval (Istanbul: Nazlı Ceyhan Sümter, 2014).

50 Todd W. Allen, Economics of Digital Comics (Chicago: Indignant Media, 2014), 1. 
books. He himself recognises that he is still experimenting with the relationship between these different textual media. ${ }^{51}$ Indeed, the success of this dual narrative strategy (video-comic or vice versa) seeks to fit the evolution of the literary landscape in the Iberian Peninsula, in which a graphic novel can now be as successful and appealing as the latest novel by Paul Auster or Michel Houellebecq. ${ }^{52}$ Saló's videos establish a multimodal extension of his books and combine different resources (music, background noise, onomatopoeias, a voice-over which narrates the plot, certain tones of voice to highlight specific moments in the video and the use of intertextuality with references to television and cinema). As we have seen, these aspects are also transferred to paper through the representation of onomatopoeias, the typography of the letters and phonological games, all with the purpose of reinforcing a message of social criticism from the multimodal point of view.

\section{Conclusion}

The use of the book trailer established Salós goal of producing a type of literature with greater outreach, both with regard to the themes he deals with and with regard to his connection with a new audience. As we have seen, the corpus of Saló's work gives us a humorous portrait of social reality. By developing parallel themes to the political and economic events of the economic crisis, the author transmits his critical vision of society and its workings.

In effect, the characteristic multimodality of Saló's visual literature entails a set of carefully selected components that, taken together, evoke an array of different meanings. More importantly, our analysis demonstrates how the cartoonist offers a clear example of the use of the 'multimodal extension' to whet viewers' appetite and internationalise a given work. In so doing, in his books and videos he succeeds in establishing the very relations of intertextuality that create new meanings while involving the reader. Such a meaningful use of humour allows the viewers/readers to reflect on the present moment by questioning vital aspects of their social reality, be they political, sociological or economic.

51 El Economista, 'Aleix Saló: “Controlar el poder político es un deber ciudadano”' [Aleix Saló: 'Controlling political power is a citizen's duty'] YouTube (16 June 2011), https:// www.youtube.com/watch?v=IQSPqkHolos.

52 Santiago García, 'Después del cómic: Una introducción' [After the comic: An introduction], in Supercómic: Mutaciones de la novela gráfica contemporánea [Supercomic: Mutations of the contemporary graphic novel], ed. Santiago García (Madrid: Errata Naturae, 2013), 7-23 (14). 
Considering the didactic dimension obtained through this interface of text and image, from the book trailer to the comic book and back, Saló's work serves to illustrate how today's comics and graphic novels have the capability of making complex and specialised topics not just more accessible and easy to understand for a lay audience, but also more enjoyable and memorable. It is a good example of how the combination of multimodality with social criticism and its circulation in a digital media economy can enable the authors of comics and graphic novels to employ a variety of different techniques in the shaping and development of their work, conscious as they are of the increasingly powerful relationship that exists between text and image in our twenty-first century imaginary.

Javier Muñoz-Basols is a senior instructor in Spanish at the Faculty of Medieval and Modern Languages at the University of Oxford. He has published on Hispanic literature, translation studies and applied linguistics. His current research focuses on the interaction between language and culture in various settings, including contemporary graphic literature and humour. He is President of the Asociación para la Enseñanza del Español como Lengua Extranjera (ASELE).

Email: javier.munoz-basols@mod-langs.ox.ac.uk

Marina Massaguer Comes is a $\mathrm{PhD}$ candidate in linguistic anthropology at the Universitat Oberta de Catalunya (UOC). Her research focuses on non-Catalan speakers in Catalonia. More specifically, she looks at how such speakers position themselves in relation to socially available categorisations connected to language, ethnocultural identity and socioeconomic status. Before undertaking doctoral studies, Marina conducted postgraduate research on the linguistic dynamics of Catalan Roma communities. She was a lector in Catalan at the University of Oxford between 2012 and 2015. Email: mmassaguerc@uoc.edu 